\title{
Effectiveness of Reef Restoration in Singapore's Rapidly Urbanizing Coastal Environment
}

\author{
Loke Ming Chou, Tai Chong Toh, and Chin Soon Lionel Ng
}

\begin{abstract}
Singapore's accelerated coastal urbanization since the $1960 \mathrm{~s}$ resulted in $65 \%$ of its coral reef habitat lost to land reclamation. Increased sedimentation reduced underwater visibility from $10 \mathrm{~m}$ then to less than $2 \mathrm{~m}$ today. Under these conditions, reef restoration to increase coral cover of degraded reefs and initiate colonization of non-reef areas remains viable considering the precise mass spawning events, active settlement and vigorous growth of coral larvae. The restoration techniques employed should withstand the high suspended sediment and destabilized reef substrate. Coral fragments were translocated from a reef close to impending port development to reefs further away in a 4-year project aimed at assessing whether 1) restoration can assist recovery of degraded reefs and 2) non-reef areas can be transformed into new reefs. Within the first three years, over 1200 fragments from 22 genera were transferred to in-situ nurseries at the recipient sites, of which almost 900 were subsequently transplanted to a degraded reef site and a non-reef site with an overall survival rate of over $80 \%$. The project's results will help to establish protocols to support management decisions on coral relocation and restoration in a rapidly urbanizing coastal environment.
\end{abstract}

Index Terms-Coastal urbanization, reef restoration, Singapore.

\section{INTRODUCTION}

Five decades of extensive coastal development has degraded much of Singapore's nearshore habitats [1]-[3]. More than $60 \%$ of coral reefs were lost to coastal reclamation that increased land area by more than $20 \%$ to $719.1 \mathrm{~km}^{2}$ since the country's independence in 1965 [4], [5]. The chronic sedimentation generated smothers reef life, while high turbidity levels attenuate light required by scleractinian corals and restrict coral development to shallow depths [6]. The reef substrate has also become less consolidated and more unstable, compromising the survival of newly settled corals [4]. Singapore's reefs are at risk of further land reclamation to support future needs [7], including plans to consolidate port operations and create a mega container terminal at Tuas on the western coast [8]-[10].

Reef restoration and rehabilitation strategies have been employed to slow the decline of Singapore's reefs and assist in the replacement of ecological structure and function of the degraded habitats [11], [12]. They are considered viable despite the continued anthropogenic impacts to the marine

Manuscript received November 21, 2016; revised March 27, 2017. This work was supported by the Singapore Maritime Institute, and Maritime and Port Authority of Singapore under Grant nos. R-347-000-190-592 and R-347-000-215-490 respectively.

The authors are with the Tropical Marine Science Institute, National University of Singapore, 18 Kent Ridge Road, Singapore (e-mail: tmsclm@nus.edu.sg, taichong.toh@nus.edu.sg, lionel.ng@u.nus.edu). environment, as annual coral mass spawning events which occur with a high degree of predictability contribute significantly to the self-seeding of Singapore's reefs [13]-[15]. The overall approach to reef restoration since the $1990 \mathrm{~s}$ is aimed at circumventing the problems of high sedimentation and destabilized substrate, and comprises physical (e.g. artificial reef deployment) and biological (e.g. nursery-rearing and transplantation of corals) techniques [12]. Based on the lessons learnt from restoration projects over the past two decades, a four-year long project was initiated as part of a long-term research framework to mitigate the potential loss of reef biodiversity from Sultan Shoal, an island with a fringing reef close to Tuas (Fig. 1).

\section{SITE ASSESSMENTS}

An Environmental Impact Assessment (EIA) was conducted in 2012 to evaluate the effects of the impending development at Tuas. Results indicated that the reef fringing Sultan Shoal $\left(1^{\circ} 14.21^{\prime} \mathrm{N}, 103^{\circ} 38.52^{\prime} \mathrm{E}\right)$, an island 0.6 ha in size located $5.48 \mathrm{~km}$ from the Singapore mainland (Fig. 1), would be impacted by Tuas dredging and reclamation activities and more than 2800 coral colonies were at risk [16]. The EIA recommended the relocation of most of the corals to other sites to help preserve the scleractinian diversity from Sultan Shoal. It was recognized that the mass coral translocation exercise would inevitably generate coral fragments, which when retrieved will be a valuable source of research material for coral restoration investigations.

In 2013, assessments were made of reefs fringing six other southern offshore islands: St. John's $\left(1^{\circ} 13.25^{\prime} \mathrm{N}\right.$, $\left.103^{\circ} 50.58^{\prime} \mathrm{E}\right)$, Hantu $\left(1^{\circ} 13.64^{\prime} \mathrm{N}, 103^{\circ} 44.80^{\prime} \mathrm{E}\right)$, Semakau $\left(1^{\circ} 12.27^{\prime} \mathrm{N}, 103^{\circ} 45.26^{\prime} \mathrm{E}\right)$, Kusu $\left(1^{\circ} 13.56^{\prime} \mathrm{N}, 103^{\circ} 51.58^{\prime} \mathrm{E}\right)$, Subar Darat $\left(1^{\circ} 12.89^{\prime} \mathrm{N}, 103^{\circ} 49.87^{\prime} \mathrm{E}\right)$, and Satumu $\left(1^{\circ} 09.60^{\prime} \mathrm{N}, 103^{\circ} 44.40^{\prime} \mathrm{E}\right)$, as well as two seawalls (Lazarus East, Lazarus West $)\left(1^{\circ} 13^{\prime} 41.76^{\prime \prime} \mathrm{N}, 103^{\circ} 51^{\prime} 19.82^{\prime \prime E}\right)$ for their suitability as recipient sites for the coral fragments. The reef sites are known to support diverse reef communities [17], while seawalls in Singapore are sufficiently stable for coral colonization [18]. The criteria used included site accessibility, water quality, availability of substrates for transplantation and tidal range. Benthic surveys and physical-chemical parameters (light levels, temperature profile, sedimentation rate, water movement and salinity) were determined at two depths (2-4 m, or 'Shallow'; 5-7 m, or 'Deep').

Based on the observed similarities to conditions at Sultan Shoal (Table I), Lazarus East, Lazarus West, and Kusu (Shallow) were selected as recipient sites for the coral fragments. Compared to Sultan Shoal, sedimentation rates at Hantu and Semakau were two to five times higher, and water 
motion at Satumu and Sisters were twice as fast.

The availability of stable substrates in the form of boulders and granite rocks at the recipient sites made them ideal for the transplantation of corals to be carried out.
The similar environmental conditions were also beneficial towards reducing stress on the transplanted corals and improving survival rates [19].

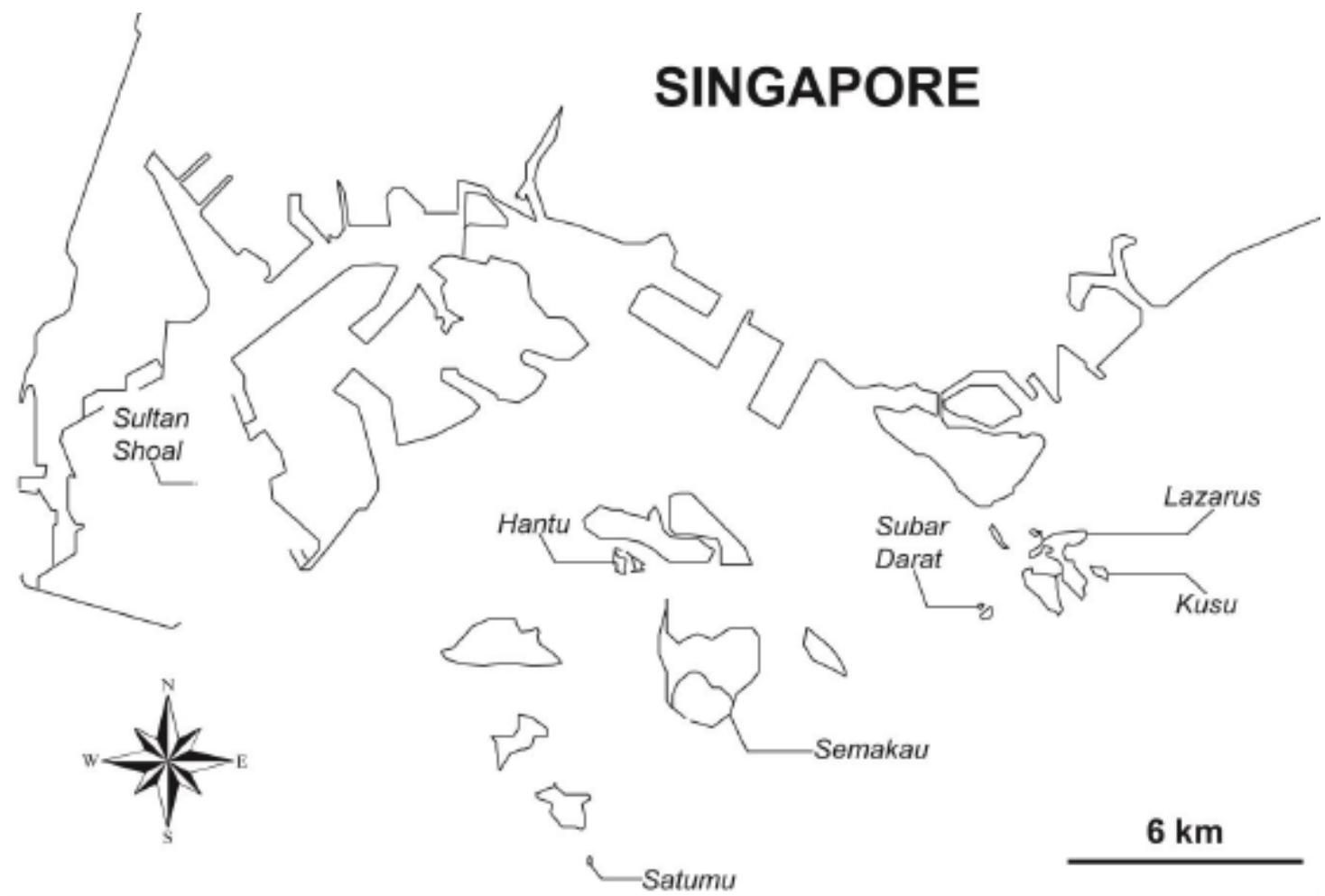

Fig. 1. Map of Singapore showing the seven study sites.

TABLE I: MEAN VALUES FOR PHYSICAL-CHEMICAL PARAMETERS RECORDED FROM STUDY SITES IN 2013

\begin{tabular}{|c|c|c|c|c|c|c|c|}
\hline Site & Location & Reef Zone & $\begin{array}{c}\text { Light levels } \\
\left(\text { microMoles } / \mathrm{s} / \mathrm{m}^{2}\right)\end{array}$ & $\begin{array}{l}\text { Temperature } \\
\left({ }^{\circ} \mathrm{C}\right)\end{array}$ & $\begin{array}{l}\text { Salinity } \\
\text { (ppt) }\end{array}$ & $\begin{array}{l}\text { Sedimentation } \\
\text { (grams/day) }\end{array}$ & $\begin{array}{c}\text { Water Motion } \\
\text { (weight loss in grams) }\end{array}$ \\
\hline \multirow{2}{*}{ Semakau } & South & Shallow & 620.63 & 30.3 & 30.1 & 2.55 & 13.96 \\
\hline & South & Deep & 176.78 & 30.32 & 30.1 & 0.94 & 8.71 \\
\hline \multirow{2}{*}{ Kusu } & East & Shallow & 197.82 & 30.34 & 30.2 & 0.28 & 13.99 \\
\hline & East & Deep & 33.53 & 30.39 & 30.2 & 0.82 & 11.14 \\
\hline \multirow{2}{*}{ Lazarus } & East & Shallow & 391.61 & 30.21 & 30.3 & 0.18 & 9.81 \\
\hline & West & Shallow & 197.41 & 30.3 & 30.2 & 0.13 & 6.38 \\
\hline \multirow{2}{*}{ Sultan Shoal- } & South & Shallow & 348.55 & 30.53 & 30 & 0.13 & 9.64 \\
\hline & South & Deep & 243.25 & 30.45 & 30.2 & 0.15 & 7.31 \\
\hline \multirow{2}{*}{ Sultan Shoal } & North & Shallow & 208.16 & 30.12 & 30 & 0.18 & 7.99 \\
\hline & North & Deep & 101.74 & 30.43 & 30 & 0.17 & 5.92 \\
\hline \multirow{2}{*}{ Subar Darat } & West & Shallow & 277.87 & 30.15 & 30.2 & 0.77 & 16.25 \\
\hline & West & Deep & 234.78 & 30.13 & 30.3 & 0.50 & 16.80 \\
\hline \multirow{2}{*}{ Satumu } & East & Shallow & 309.51 & 30.84 & 30 & 0.29 & 13.76 \\
\hline & East & Deep & 196.81 & 30.74 & 30 & 0.31 & 16.71 \\
\hline \multirow{2}{*}{ Satumu } & West & Shallow & 953.00 & 30.72 & 30 & 0.08 & 15.20 \\
\hline & West & Deep & 275.70 & 30.641 & 30 & 0.23 & 10.96 \\
\hline Hantu & West & Shallow & 684.32 & 29.96 & 30 & 0.42 & 12.09 \\
\hline
\end{tabular}

\section{ESTABLISHMENT OF CORAL NURSERIES AND CORAL PROPAGATION}

Coral nurseries are beneficial to reef restoration efforts as they provide a sheltered environment that facilitates the growth of coral material prior to transplantation to degraded sites [20].

Two nurseries were established on the sandy seabed adjacent to the Lazarus East and Lazarus West seawalls, while a third was sited at Kusu (nursery areas of $36.5 \mathrm{~m}^{2}, 12$ $\mathrm{m}^{2}$, and $2.5 \mathrm{~m}^{2}$ respectively). Coral nursery tables were constructed from polyvinylchloride frames elevated 0.5 to $1 \mathrm{~m}$ above the substrate. Plastic mesh nets were mounted taut across the tops of the nursery tables to facilitate the attachment of coral fragments, as well as reduce sediment accumulation around the base of the attached fragments. (Fig. 2)

Loose coral fragments lying on the Sultan Shoal reef floor 
during the mass coral translocation were collected and secured to the nursery tables in 2014. These fragments, collectively known as "corals of opportunity" (COP), would have otherwise perished from being swept about by currents [21]. In total, 1251 fragments from 22 coral genera were raised in the nurseries (Table II). Overall survivorship after one year was $92 \%$. Corals of the genera Turbinaria, Pectinia and Pocillopora had the lowest survival rates of $75 \%, 71.6 \%$ and $65.7 \%$ respectively (Table II).

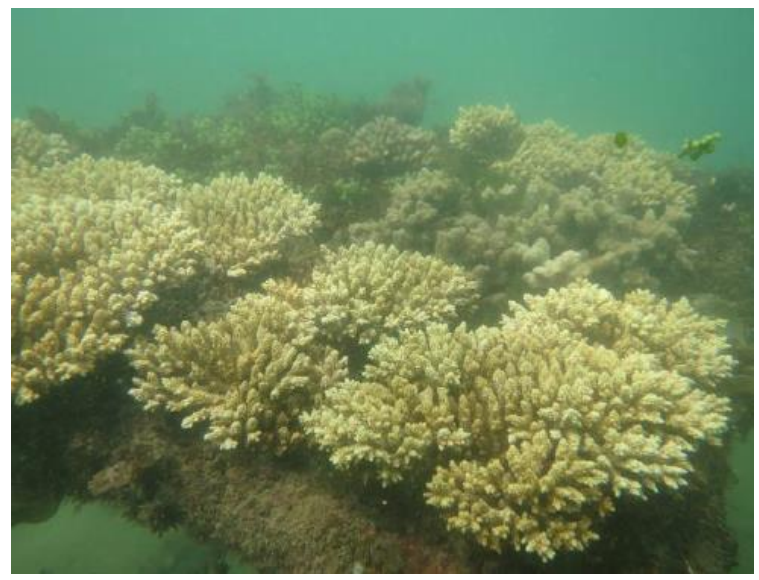

Fig. 1. 'Corals of opportunity' reared at the in situ nursery.

Thirty-six fragments from each of six species (Podabacia crustacea, Echinopora lamellosa, Merulina ampliata, Hydnophora rigida, Pocillopora damicornis, Platygyra sinensis) that spanned the range of coral growth forms (foliose, branching, massive) in Sultan Shoal were selected for further monitoring in the nursery. Compared to earlier restoration efforts in Singapore where $61 \%$ of coral fragments survived after a six-month nursery-rearing period [22], survival rates in the current study were high (99\% in eight months), with mortality recorded from only one $H$. rigida and two $M$. ampliata fragments. The high survival is attributed to the high frequency of maintenance effort, which included scrubbing of the supporting mesh net material to remove fouling organisms.

In addition, mean colony sizes of all species increased. Pocillopora damicornis and $H$. rigida exhibited the fastest growth (by 1.9 and 1.8 times respectively), while $P$. crustacea and $P$. sinensis grew slower (by 1.2 and 1.1 times respectively) [23]. Growth in the nursery is essential to improve survival chances upon transplantation, as smaller sized corals are more affected by environmental stressors than larger ones. The results demonstrated the feasibility of propagating COPs in nurseries to supplement reef restoration efforts instead of harvesting directly from source colonies on the reef.

\section{Coral Transplantation}

Following methods described by $\mathrm{Ng}$ et al. [24], a total of 213 live coral fragments ( $P$. crustacea, E. lamellosa, $M$. ampliata, $H$. rigida, $P$. damicornis, $P$. sinensis) were transplanted on the granite seawall off Lazarus East and monitored for seven months. The overall survival rate of the transplanted corals was $88 \%$. All transplants of E. lamellosa and $H$. rigida survived, while those of $P$. damicornis had the lowest survival rate $(47 \%)$. Mean sizes of the transplants reduced slightly in the first month - likely due to transplantation stress - but increased in subsequent months.

TABLE II: GENERA COLLECTED FROM SULTAN SHOAL AND SURVIVAL RATES OF CORAL FRAGMENTS AFTER ONE YEAR OF REARING IN NURSERIES

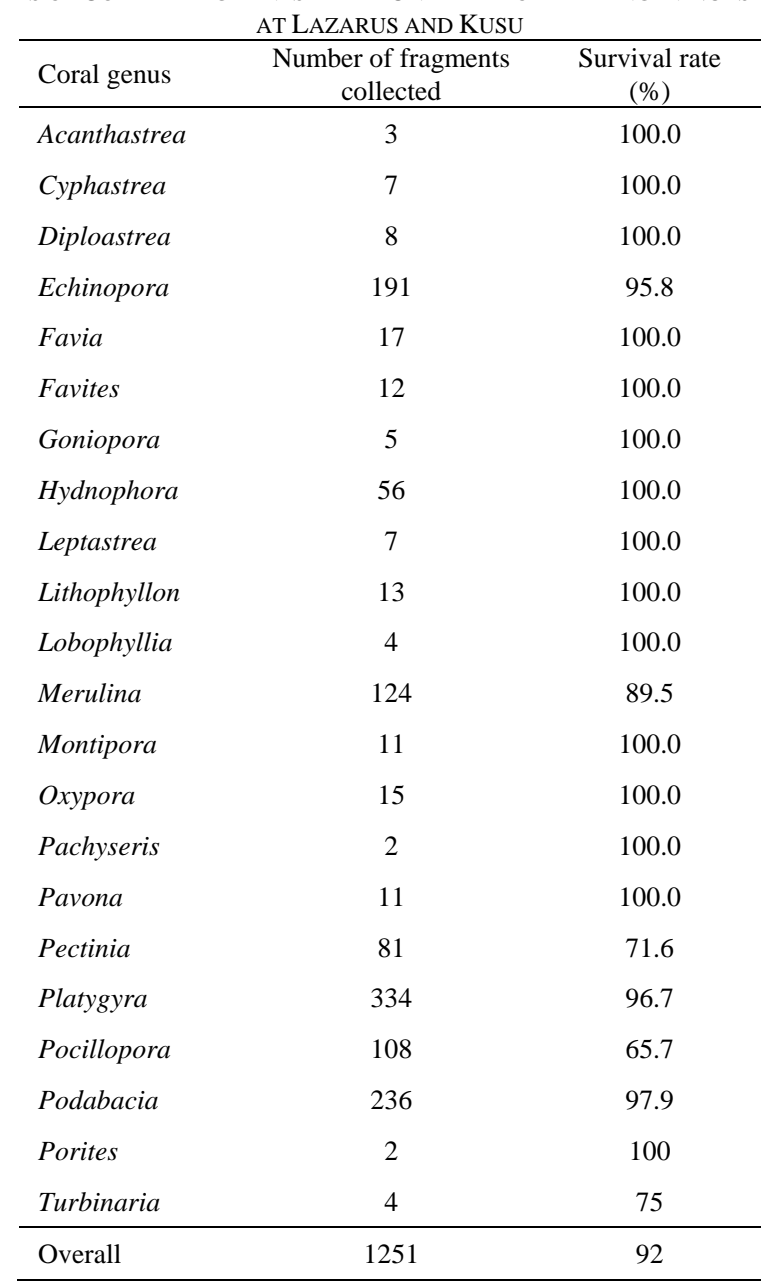

Transplants of $P$. crustacea and $P$. damicornis were most impacted by corallivorous gastropods (Drupella spp). Similar to the nursery phase, transplants of $P$. damicornis and $H$. rigida grew the fastest (by 1.4 and 1.3 times respectively), while those of the remaining species increased by 1.1 to 1.2 times in size [23]. Coral cover at the transplant site rose to $20 \%$ from $3 \%$, and generic richness increased from two to eight. The high transplant survival rates showed that it was possible to ecologically engineer subtidal seawalls and enhance the biodiversity of these artificial structures.

From 2015 to 2016, a total of 904 coral fragments from 17 genera (Acanthastrea, Echinopora, Favia, Favites, Goniopora, Hydnophora, Merulina, Mycedium, Pachyseris, Pavona, Pectinia, Platygyra, Pocillopora, Podabacia, Psammacora, Symphyllia, Turbinaria) were transplanted to the seawalls at Lazarus East and Lazarus West, as well as the reef fringing Kusu (Table III). This generated a total restored area of $422 \mathrm{~m}^{2}$ (150 $\mathrm{m}^{2}$ degraded reef and $272 \mathrm{~m}^{2}$ new reef). Monitoring programs are in place to assess the long term effectiveness of these habitat enhancement initiatives. Species that responded favorably will be selected for future efforts to assist the recovery of degraded sites or hasten coral colonization on artificial structures.

This study has demonstrated the viability of harnessing 
restoration strategies to improve the biodiversity of degraded reefs, and to create new habitats that contribute to the ecological functioning of urbanized coastal environments.
The findings will be relevant in helping to reduce the loss of reef life from future coastal development.

TABLE III: SUMMARY OF CORAL RESTORATION EFFORTS

\begin{tabular}{|c|c|c|c|c|}
\hline Location & Habitat type & Coral species & Number of fragments transplanted & Area restored \\
\hline \multirow{3}{*}{ Kusu } & \multirow{3}{*}{ Degraded reef } & Pachyseris speciosa & 120 & \multirow{3}{*}{$150 \mathrm{~m}^{2}$} \\
\hline & & Platygyra sinensis & 90 & \\
\hline & & Pocillopora damicornis & 90 & \\
\hline \multirow{18}{*}{ Lazarus East } & \multirow{18}{*}{ Seawall } & Pocillopora damicornis & 156 & \multirow{18}{*}{$224 \mathrm{~m}^{2}$} \\
\hline & & Podabacia crustacea & 104 & \\
\hline & & Merulina ampliata & 70 & \\
\hline & & Platygyra sinensis & 68 & \\
\hline & & Echinopora lamellosa & 36 & \\
\hline & & Hydnophora rigida & 35 & \\
\hline & & Favites pentagona & 6 & \\
\hline & & Goniopora sp. & 5 & \\
\hline & & Symphyllia recta & 4 & \\
\hline & & Favites halicora & 3 & \\
\hline & & Pavona decussata & 3 & \\
\hline & & Acanthastrea rotundoflora & 3 & \\
\hline & & Turbinaria mesenterina & 2 & \\
\hline & & Turbinaria peltata & 2 & \\
\hline & & Mycedium elephantotus & 2 & \\
\hline & & Goniastrea retiformis & 1 & \\
\hline & & Pachyseris speciosa & 1 & \\
\hline & & Psammocora contigua & 1 & \\
\hline \multirow{3}{*}{ Lazarus West } & \multirow{3}{*}{ Seawall } & Echinopora lamellosa & 37 & \multirow{3}{*}{$38 \mathrm{~m}^{2}$} \\
\hline & & Platygyra sinensis & 32 & \\
\hline & & Podabacia crustacea & 32 & \\
\hline
\end{tabular}

\section{ACKNOWLEDGMENT}

We thank the Singapore Maritime Institute, and the Maritime and Port Authority of Singapore for supporting this research through grant numbers R-347-000-190-592 and R-347-000-215-490 respectively awarded to the Tropical Marine Science Institute of the National University of Singapore. The authors are also thankful to the numerous volunteers under the public engagement component of the second project grant who assisted enthusiastically with the field work.

\section{REFERENCES}

[1] L. M. Chou, "Marine habitats in one of the world's busiest harbours," The Environment in Asia-Pacific Harbours, Netherlands: Springer, 2006, pp. 377-391.

[2] T. K. Yee, W. F. Ang, S. Teo, S. C. Liew, and H. T. W. Tan, "The present extent of mangrove forests in Singapore," Nature in Singapore, vol. 3, pp. 139-145. 2010.

[3] S. M. Yaakub, L. J. McKenzie, P. L. Erftemeijer, T. Bouma, and P. A. Todd, "Courage under fire: Seagrass persistence adjacent to a highly urbanised city-state," Marine Pollution Bulletin, vol. 83, no. 2, pp. 417-424, 2014.

[4] K. P. P. Tun, "Optimisation of reef survey methods and application of reef metrics and biocriteria for the monitoring of sediment-impacted reefs," Ph.D. dissertation, Dept. Biol. Sci., National University of Singapore, 2012.

[5] Singapore Department of Statistics. (2016). Latest data. [Online]. Available: http://www.singstat.gov.sg/statistics/latest-data\#14
[6] Y. Loya, "Effects of water turbidity and sedimentation on the community structure of Puerto Rican corals," Bulletin of Marine Science, vol. 26, no. 4, pp. 450-466, 1976.

[7] Ministry of National Development. (2013). Our land use plan. [Online]. Available: http://www.mnd.gov.sg/landuseplan/

[8] C. Tan, "Work on Tuas megaport starting soon," The Straits Times, February 2015.

[9] Foo, "Tuas to have mega port for all container shipments," The Straits Times, October 2, 2012.

[10] J. S. L. Lam, "Strategy of a transhipment hub: The case of Port of Singapore," Dynamic Shipping and Port Development in the Globalized Economy, Palgrave Macmillan UK, 2016, pp. 12-38.

[11] L. M. Chou, T. Yeemin, A. R. B. G. Yaman, S. T. Vo, and P. Alino, "Coral reef restoration in the South China Sea," Galaxea, Journal of Coral Reef Studies, vol. 11, no. 2, pp. 67-74, 2009.

[12] C. S. L. Ng, T. C. Toh, and L. M. Chou, "Coral restoration in Singapore's sediment-challenged sea," Regional Studies in Marine Science, 2016.

[13] Y. C. Tay, P. A. Todd, P. S. Rosshaug, and L. M. Chou, "Simulating the transport of broadcast coral larvae among the Southern Islands of Singapore," Aquatic Biology, vol. 15, no. 3, pp. 283-297, 2012.

[14] K. P. P. Tun, “An annual sea show," The ALUMNUS, issue 90, p. 6, July-September 2012.

[15] T. C. Toh, C. S. L. Ng, K. B. Toh, L. Afiq-Rosli, D. Taira, H. Loke, and L. M. Chou, "Mass brooding of the blue octocoral, Heliopora coerulea on a sedimented equatorial reef," Marine and Freshwater Behaviour and Physiology, vol. 49, no. 1, pp. 69-74, 2016.

[16] Maritime and Port Authority. (2015). Relocated corals thriving at new sites. [Online]. Available: http://www.mpa.gov.sg/web/portal/home/media-centre/news-releases/ detail/0c674e29-62ea-49db-8e39-eab37b1d6834

[17] D. Huang, K. P. P. Tun, L. M. Chou, and P. A. Todd, “An inventory of zooxanthellate scleractinian corals in Singapore, including 33 new records," Raffles Bulletin of Zoology, supplement 22, pp. 69-80, 2009. 
[18] C. S. L. Ng, D. Chen, and L. M. Chou, "Hard coral assemblages on seawalls in Singapore," Contributions to Marine Science, pp. 75-79, 2012.

[19] Edwards, Reef Rehabilitation Manual, The Coral Reef Targeted Research \& Capacity Building for Management Program, Australia, 2010.

[20] Rinkevich, "Conservation of coral reefs through active restoration measures: recent approaches and last decade progress," Environmental Science \& Technology, vol. 39, no. 12, pp. 4333-4342, 2005.

[21] C. S. L. Ng, and L. M. Chou, "Rearing juvenile 'corals of opportunity' in in situ nurseries - A reef rehabilitation approach for sediment-impacted environments," Marine Biology Research, vol. 10, no. 8, pp. 833-838, 2014.

[22] L. Bongiorni, D. Giovanelli, B. Rinkevich, A. Pusceddu, L. M. Chou, and R. Danovaro, "First step in the restoration of a highly degraded coral reef (Singapore) by in situ coral intensive farming," Aquaculture, vol. 322, pp. 191-200, 2011.

[23] T. C. Toh, C. S. L. Ng, H. X. Loke, D. Taira, K. B. Toh, L. Afiq-Rosli et al., "A cost-effective approach to enhance scleractinian diversity on artificial shorelines," Ecological Engineering, vol. 99, pp. 349-357, 2017.

[24] C. S. L. Ng, S. C. Lim, J. Y. Ong, L. M. S. Teo, L. M. Chou, K. E. Chua et al., "Enhancing the biodiversity of coastal defence structures: Transplantation of nursery-reared reef biota onto intertidal seawalls," Ecological Engineering, vol. 82, pp. 480-486, 2015.

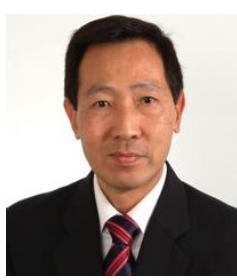

Chou Loke Ming obtained a PhD in zoology from the University of Singapore in 1976. He retired in 2014 after 37 years of service to the National University of Singapore and has since been adjunct research professor at the Tropical Marine Science Institute, with past and current joint adjunct appointments at the Department of Biological Sciences and the Lee Kong Chian Natural History Museum.

His research on coral reef biology and integrated coastal managemen covers Southeast Asia and he coordinated and edited the "2009 State of the Marine Environment Report for the East Asian Seas" for the United Nations Environment Programme. His current research focus is reef restoration with a particularly interest in how corals can be re-established in highly turbid conditions of rapidly developing coastal areas. Since 1998, he has actively contributed to the regular regional compilation of the health of coral reefs for the "Status of Coral Reefs of the World" reports published by the Australian Institute of Marine Science and the "Status of Coral Reefs of East Asia" published by Japan's Ministry of the Environment. He is currently an Honorary Fellow of the Singapore Institute of Biology and a Fellow of the Singapore National Academy of Science.

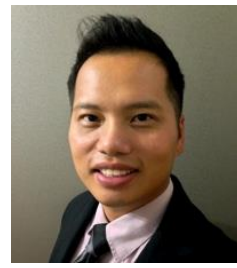

Toh Tai Chong obtained his BSc (Hons) in biological sciences from Nanyang Technological University in 2009 and a $\mathrm{PhD}$ in Life Sciences from the National University of Singapore in 2014.

Upon graduation, he started his postdoctoral training as a research fellow in the Tropical Marine Science Institute and holds a concurrent position as a lecturer in the College of Alice and Peter Tan. His research focuses on coral reef conservation in Southeast Asia and the use of ecological engineering in coastal cities. To date, he has published over 20 scientific papers and through his work he hopes to aid practitioners and policy makers in their decision making.

In addition, he is an active volunteer with various NGOs including Seakeepers Asia, Singapore Environmental Council and the International Coastal Cleanup Singapore. Through these education and outreach efforts, he helps to promote eco-literacy and environmental sustainability in the community. In recognition of his efforts, he has received various research and teaching excellence awards and was recently named the valedictorian of his graduating class.

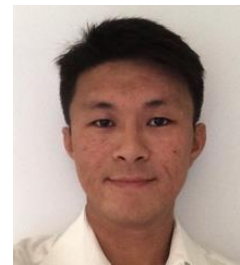

Ng Chin Soon Lionel obtained his BSc (Hons) (life sciences) in 2008 and the MSc (environmental management) in 2015 , and is currently pursuing a $\mathrm{PhD}$ (biological sciences) at the National University of Singapore.

$\mathrm{He}$ worked as a research assistant at both the Tropical Marine Science Institute and the Departmen of Biological Sciences (NUS) from 2008 to 2016. His research interests include coral reef ecology, marine conservation and environmental management.

$\mathrm{He}$ led and co-authored numerous peer-reviewed publications as well as popular science articles. Most recently, he won the Best Dissertation award for his MSc work on coral reef restoration in Singapore. 